\title{
Bullying and organisational politics in competitive and rapidly changing work environments
}

Published in International Journal of Management and Decision

Making, 4, 1, 35-46

Denise Salin

Swedish School of Economics and Business Administration

Department of Management and Organisation

P.O.Box 479, FIN-00101 Helsinki, Finland

e-mail: denise.salin@hanken.fi, telephone +358-40-3521 563 


\section{Bullying and organisational politics in competitive and rapidly changing work environments}

\section{Denise Salin}

This paper argues that workplace bullying can in some cases be a form of organisational politics, that is, a deliberate, competitive strategy from the perspective of the individual perpetrator. A cross-sectional study conducted among business professionals revealed that there was a correlation between a politicised and competitive climate and bullying. This finding implies that globalisation, increased pressures for efficiency, and restructuring, which limits the number of management positions and thereby contributes to increased internal competition, may lead to more bullying. The findings have important implications for management, since the possible political aspects of bullying must be taken into account in order to be able to undertake successful prevention and intervention measures.

Key words: workplace bullying; workplace aggression; mobbing; organisational behaviour; organisational politics; internal competition; business professionals; restructuring; organisational change; work environment

Biographical notes: Denise Salin is Lecturer at the Swedish School of Economics and Business Administration in Helsinki, Finland. She teaches in the Department of Management and Organisation and her major academic and research interest is organisational behaviour. In particular, she is interested in the field of conflicts and bullying in the workplace. She is currently completing her $\mathrm{PhD}$ on 'Workplace Bullying among Professionals: Prevalence, Organisational Antecedents and Gender Differences'. 


\section{Introduction}

During the past decade workplace bullying and related terms such as mobbing, employee abuse, workplace aggression and victimisation have received growing attention in organisation research. Studies have shown that bullying not only has severe negative effects on the well-being of individual employees [1] but that it also has negative consequences for the organisations concerned. Some researchers have even tried to calculate the costs of bullying and shown that bullying can be costly both for individual organisations and for society as a whole, in terms of lost productivity, increased absenteeism, and higher turnover of personnel [2,3]. The negative outcomes of bullying thus make it important to increase our understanding of bullying as well as the mechanisms behind it, in order to ensure that management at all levels can take appropriate prevention and intervention measures to reduce the prevalence and mitigate the negative consequences of bullying.

In recent studies several researchers have tried to identify personality traits and organisational factors associated with workplace bullying and aggression [4-10]. For example, a number of researchers and writers have focussed on explaining bullying by examining perpetrator characteristics [11-13]. In other studies, certain victim characteristics, such as negative affectivity, dependence, introversion, instability and conscientiousness have been found to be associated with bullying $[4,10,14]$.

Rather than studying the individual, other researchers, predominantly in Northern Europe, have chosen to look for explanations in organisational factors and in deficiencies in the work environment $[5,15]$. For example, they have examined the role of organisational structure, the style of leadership, job design and social climate. Bullying has been shown to be more frequent in large [16] and bureaucratic organisations [17], where the perpetrator is more invisible. Furthermore, a very authoritarian style of leadership $[8,18]$ or weak or laissez-faire styles of leadership $[5,15,18]$ have both been found to be associated with bullying. Similarly, role conflict, role ambiguity, high co-operation requirements, and low control of work and time have all been linked to increased bullying [5,9]. Also, perceived stress, a high workload, and a strained atmosphere can lead to bullying $[5,8,19]$. In fact, bullying seems to be prevalent in organisations where employees 
are dissatisfied with the social climate and the internal communication $[5,8]$. Finally, bullying has been found to be more common in organisations that support, allow, or accept such behavior, or where bullies feel that they can 'get away with it' or where it is accepted as part of a 'tough' climate $[6,20]$. In such environments new employees and managers can also become socialised into treating bullying as a normal feature of working life: ‘monkey see, monkey do' behaviour as described by Robinson and O'Leary-Kelly [21].

In recent years a number of authors have particularly emphasised the relationship between bullying and increasing pressures for efficiency, speed, and increased external and internal competition. For example, Hoel and Cooper [18], McCarthy [22] and Sheehan [23] have stressed the effects of restructuring and organisational change. Restructuring and downsizing lead to the elimination of organisational layers and positions, thereby reducing promotion opportunities, increasing workloads and internal competition, and lowering job security. This in turn leads to higher levels of pressure and more stress, lowering thresholds for aggression and increasing the potential benefits of 'eliminating' threats and burdens. Similarly, Baron and Neuman [24] found that cost cutting, for example downsizing, layoffs, and pay cuts or freezes, as well as organisational changes, such as restructuring and reengineering, were significantly related to expressions of hostility and obstructionism.

These aforementioned findings suggest that bullying is not necessarily an 'irrational' behavior, due for example to unwanted personality traits or to dissatisfaction in the workplace. Indeed, a few researchers have even acknowledged the fact that in some instances bullying can have political dimensions and be a 'rational' choice, that is a deliberate strategy for improving one's own position, by sabotaging the performance of competitors or by getting rid of persons considered as threats or burdens. For example, bullying has been described as a 'foul game' in organisations [25], as 'personnel work with other means' [26-27], as 'elimination of competitors' [28] or as a 'rent-seeking strategy' [29] that can be rational from the point of view of the perpetrator.

There are several instances where it might be individually 'rational' or rewarding to bully a colleague or a subordinate. Firstly, tough internal competition seems to 
make an organisation particularly prone to bullying [8,30]. In addition, the reward system may contribute to bullying, for example by giving an employee an incentive to bully a colleague when the remuneration is based on the relative ranking of employees [29]. By sabotaging the work performance of a colleague, the perpetrator may improve his or her own ranking. Secondly, colleagues may want to 'punish' very high-performing colleagues who are perceived as raising the barrier for others. Bullying is thus used to discipline colleagues who violate established production norms [7,29]. Finally, if an employee is evaluated and remunerated based on the performance of the team he or she belongs to, he or she may want to 'punish' and expel very low-performing team members. In the same vein, Klein [31] concluded that where a work-measurement system using quantity of production was used as a primary criterion for performance evaluation, people tended to increase their effort, which could in turn negatively affect group cohesion as group members perceived others as competing.

The reward system and expected benefits may not only contribute to horizontal bullying, but also may contribute to vertical bullying, that is bullying from superiors [29]. Superiors may want to eliminate very high-performing subordinates perceived as threats, or very low-performing subordinates who are perceived as liabilities for the department. Similarly, the Banking, Insurance, and Finance Union (BIFU) in the UK has argued that intimidation and victimisation become almost unavoidable in environments where there are ever-increasing pressures on staff and managers to meet targets. In line with this they criticise, for example, performancerelated pay and argue that such policies may 'virtually institutionalize the practice [of workplace bullying] and provide the means for its perpetuation.' [32]

As illustrated above, some researchers have argued that bullying can be a competitive strategy in organisations. Indirectly, therefore, it may be inferred that there is a link between bullying and organisational politics. Organisational politics here refers to the phenomenon when individuals or groups deliberately act in a way that will protect or enhance their own self-interests, when their actions may or may not be in the best interests of other individuals, groups, or even the organisations to which the actors belong [33-34]. Tactics of organisational politics can thus be seen as part of a competitive strategy, where the aim is to improve the position of the perpetrator(s). 
A key aim of the study from which this article is drawn is to empirically test that there is in fact a relationship between a high degree of perceived organisational politics and the occurrence of bullying. Secondly, the aim is to analyse to what extent victims and observers of bullying themselves think of and discuss bullying as a form of organisational politics and provide examples of this. Additionally, the effects of work overload and internal competition, both of which are often associated with organisational politics, are analysed.

\section{Method}

A cross-sectional survey was conducted in cooperation with The Finnish Association of Graduates in Economics and Business Administration (SEFE), a Finnish nation-wide professional organisation for employees holding a university degree in business studies. The organisation has approximately 26,000 members and the questionnaire was sent to 1,000 randomly drawn members. A total of 385 questionnaires were returned, giving a response rate of $38.5 \%$. However, 8 questionnaires were excluded because they were completed incorrectly.

The questionnaire employed in the study included background questions about the respondents and the employing organisation, questions about the respondents' perceptions of perceived work overload, internal competition and organisational politics. The respondents were employed in a wide variety of organisations, the majority (82\%) being within the private sector. Over four-fifths of the respondents were employed in either managerial or expert positions and mean tenure was 6.9 years, ranging from 2 weeks to 36.9 years. As for the demographics of the respondents, the mean age was 39.2, ranging from 24 to 64 years. Women accounted for $57.3 \%$ of the sample and men for $42.7 \%$.

Two different measures of bullying were utilised. Perceived organisational politics was measured with the Perceptions of Politics Scale (POPS) developed by Kacmar and Ferris [35]. However, some minor changes in wording suggested by Nye and Witt [36] were adopted. The instrument consisted of 12 statements concerning the perceived degree of organisational politics and included for example statements such as 'Some people build up themselves by tearing others down' and 'Favouritism not merit gets people ahead'. The 12 statements can be found in 
Appendix A, and in this article the term organisational politics is thus measured against these criteria. In addition, the degree of internal competition was measured with a single question. Four questions on stress, or work overload, were taken from Reichel and Neumann [37]. Respondents were asked to judge all the statements on a Likert-type scale from 1 (strongly disagree) to 5 (strongly agree). The internal consistency of both scales was high: Cronbach's alpha was 0.88 for organisational politics and 0.85 for work overload.

In previous studies different strategies have been used for measuring bullying [3839]. Specific questionnaires, such as the Negative Acts Questionnaire (NAQ) $[18,40]$ and the Leymann Inventory of Psychological Terrorization (LIPT) [41], have been developed to measure if respondents have been subjected to specific, negative acts with a pre-specified frequency over a longer period of time. In contrast, other studies have relied on giving the respondents a short definition of bullying and asking them to judge whether or not they have been subjected to such behaviour $[8,16]$.

In this study both methods were used in order to exploit the strengths of each. Firstly, the respondents were asked to indicate how often they had experienced 32 listed negative and potentially harassing acts over the past 12 months. The listed acts were primarily based on the Negative Acts Questionnaire, although some minor modifications were made. In addition, two items were adopted from the Leymann Inventory for Psychological Terrorization, namely, 'Somebody causes you economic or material damages' and 'You are physically isolated'. Finally, based on other literature on bullying two additional acts were included namely, 'Somebody tries to sabotage your performance', and 'You are excluded from social events'. For all the 32 acts the respondents were asked to indicate how often they had experienced them on a scale from 1 (never) to 5 (daily). Those who had experienced at least one of the acts on at least a weekly basis were classified as bullied $[2,18]$.

Secondly, the respondents were asked to classify themselves as bullied or nonbullied based on the short definition below. In addition, all respondents were asked whether they had observed somebody being bullied at work during the past 12 
months. For both questions the respondents were given five options from 1 (never) to 5 (daily). Respondents were given the following definition of bullying:

'Bullying' is here used to denote repeated and persistent negative acts that are directed towards one or several individuals, and which create a hostile work environment. When subjected to bullying the targeted person has difficulties defending him- or herself; it is therefore not a conflict between parties of equal strength.

Finally, those who had been subjected to or witnessed bullying were encouraged to describe their experiences in their own words. The stories were analysed to find evidence of bullying being used as a form of organisational politics and were principally used for illustrative purposes.

\section{Results}

Based on the short definition above, 8.8\% of the respondents reported that they had been bullied during the past 12 months. However, as many as $24.1 \%$ reported that they had been subjected to at least one of the 32 negative acts on a weekly basis in the same time period. An even higher number of employees reported that they had witnessed others being bullied at work. In fact, based on the definition given, 30.4 $\%$ reported that they had observed bullying in their own workplace [39].

At the beginning of this study it was suggested that there is a positive relationship between a high degree of perceived organisational politics and bullying. In the analysis, bullying was measured as the respondent's own perception of how often he or she had been bullied, from 1 (never) to 5 (daily). The correlation coefficients are shown in Figure 1. As shown in the figure, a significant correlation was found between a high degree of organisational politics and perceptions of being bullied in the workplace. 
In order to further study the association between bullying and a high degree of organisational politics, a t-test was performed to compare the means of perceived degree of organisational politics between the group consisting of those classifying themselves as bullied and the group consisting of those classifying themselves as not bullied. In this analysis all those who had classified themselves as bullied, that is had chosen a value between 2 (now and then) and 5 (daily), were grouped together. The difference between the bullied group and the non-bullied group, 3.55 versus 2.70, was statistically significant $(\mathrm{t}=-6.691, \mathrm{df}=364, \mathrm{p}<0.00)$. The same procedure was repeated for the other way of measuring bullying, that is those who had been subjected at least weekly to at least one of the 32 listed acts or behaviours in the Negative Acts Questionnaire and those who had not. The difference, 3.28 versus 2.61, was statistically significant $(\mathrm{t}=-8.124, \mathrm{df}=365, \mathrm{p}<0.00)$ as well.

Additionally, in order to verify the reports of victims observers' reports were analysed to see if their reports supported the assumed relationship between bullying and organisational politics. The perceived degree of organisational politics was compared for those who had observed bullying in their current workplace and those who had not. The reported mean of organisational politics for those who had observed bullying was 3.07, as compared to 2.64 for those who had not observed bullying. This difference was also statistically significant $(t=-5.221, d f=350$, $\mathrm{p}<0.00$ ), which provides further support for a relationship between a high degree of organisational politics and bullying.

In line with this, the written stories by observers of bullying also showed that bullying was sometimes seen as a deliberate attempt to get rid of unwanted persons, for example employees who were considered threats or burdens. Two examples of this follow:

A supervisor, who is a colleague of mine, got a new subordinate, whom she obviously experienced as a threat to her own career. The new subordinate was not invited to common meetings, was publicly scoffed at, etc. When the subordinate had risen to the same hierarchical level, it was payback time. The former supervisor was slandered, was excluded from the work community, and 
it was generally considered that she was not capable of handling her work tasks. [42]

There is a tendency at high levels in the organisation to eliminate people who are considered difficult or who are not liked. In other words, they are 'sent to Coventry'.

Initially I also suggested that work overload and internal competition may lead to bullying. The correlations that were found in this study indeed indicated a relationship between bullying and work overload and between bullying and internal competition. However, both of these were also significantly correlated with organisational politics. When controlling for the reported degree of organisational politics, the relationships were no longer significant on the $\mathrm{p}<0.05$ level (see Figure 2). Nevertheless, the relationship between bullying and internal competition was also mentioned in the written stories. For example two respondents wrote as follows:

Maybe it is wrong to call it bullying. However, today competition is tough. When a young woman with experience and an academic degree enters somebody else's territory, it can be a hard blow to a 50+-year-old lady. The lady withholds information, is unwilling to help, and is ingratiating (towards the manager) etc.

In a company of consultants, situations often arise, where seemingly equal colleagues compete for the same jobs. Since recognition is given primarily based on billing, it is natural that elbow tactics are used to boost one's own position, 
which in turn easily leads to the perception that somebody is standing in the way, and therefore gets bullied.

\section{Discussion}

Organisational politics involves intentional acts of influence to enhance or protect the self-interest of individuals and groups [33,34,43]. This study revealed a positive relationship between a high degree of perceived organisational politics and bullying. This finding indicates that in some cases workplace bullying might be a game, that is, a way of furthering self-interest by eliminating unwanted persons considered threats or burdens, or sabotaging their work performance. Similarly, diTomaso [44] has shown how sexual harassment can be used as a means for men to control women who try to challenge male authority and compete for 'male jobs'.

Organisational politics is an important social process, which has the potential of being both functional and dysfunctional for the organisation [33]. As for the functional roles of politics, it may allow for certain forms of flexibility that other systems of influence do not allow for, it may be required to promote necessary organisational change blocked by the legitimate systems of change, and it may ease the path for the execution of decisions [45]. However, it becomes negative when self-interests collide with or erode organisational interests. For example, important information can be filtered or distorted in order to enhance the image of the perpetrator [46]. In addition, studies have shown that perceived political behavior is associated with lower job satisfaction, job anxiety, and intent to exit the organization [47-48]. Deliberately improving, or aiming to improve, one’s own position through bullying or harassment can be seen as negative examples of organisational politics, since they have negative effects on both job satisfaction and the psychological and physical health of victims $[1,9,40]$ and can lead to costs for the organisations in term of increased absenteeism, higher turnover of personnel, and lower productivity $[3,15,49]$.

A review of the literature on organisational politics showed that several of the tactics used to improve one's own position could be classified as bullying. For 
example, Allen and colleagues [33] reported 'attacking or blaming others' or 'use of information' as the two most commonly used tactics in organisational politics. These categories thus included scapegoating, actively making a rival look bad, and withholding or distorting information, all actions that can be interpreted as bullying if they occur systematically over a long time.

The study further revealed significant correlations between organisational politics and stress and internal competition. Thus, organisational politics seems to thrive in competitive and hectic work environments. Indirectly, this also means that bullying is more frequent in these environments, which is supported by previous studies $[5,8,19,30]$.

A limitation of the present study was that the same respondents were asked to rate both the work environment and the existence of bullying. It can be assumed that employees subjected to bullying are in general somewhat more likely to rate the environment more negatively, which might have slightly affected the results. Nevertheless, the fact that those who had observed bullying also reported higher levels of perceived organisational politics gives the findings more credibility.

Although a clear relationship between organisational politics and bullying was found in this study, it should also be kept in mind that bullying is usually a multicausal problem. Thus, bullying is often the result of a variety of enabling, motivating and precipitating structures and processes that interact [50]. Even though there might be an incentive to bully a very high or low achieving colleague or subordinate, bullying is very rare unless certain conditions are met. Firstly, there must be a perceived power difference between the target and the offender(s) to make bullying possible. Secondly, bullying is rare unless the offender at least subconsciously assesses the expected costs of bullying as lower than the expected benefits [51]. In addition, organisational changes, such as downsizing, restructuring, or a change in management are often needed to actually trigger the onset of bullying [18,22,24]. Moreover, several individual characteristics of perpetrators and victims can play a part in the bullying process [4,13].

However, when studying bullying the analysis should not be limited only to the individual and organisational levels. Increasingly, a number of researchers are pointing to larger societal forces, such as globalisation and the liberalisation of 
markets, the ever-increasing struggle for efficiency, work intensification, and reliance on performance-related reward systems, which may lead to an increase in bullying and violating and abusive conduct by managers and co-workers [22-23,5253]. McCarthy [22] argues that 'pressures generated by these forces lower the threshold at which managers, particularly those operating at the limits of their skills competencies, might adopt bullying behaviours - even if involuntarily.' Similarly, Wright and Smye [52] claim that some workplaces have gone far beyond beings simply 'tough' and 'competitive' and are in fact 'becoming uncivilized'. Notably, in the 1990's marketplace philosophies were imported into new sectors, for example schools and hospitals, with the aim of making them more efficient and more responsive. However, researchers have concluded that these changes have had negative effects on the well-being and motivation of some employees, thereby fostering an atmosphere of bullying [54].

It is important to note that all these aforementioned societal forces may affect all three categories of bullying. Firstly, they may facilitate bullying by reducing the costs and risks associated with bullying, as bullying is turned into acceptable and normal behaviour. Secondly, these forces may increase the value of bullying as a way of eliminating 'burdens' and 'threats' when internal competition increases. Thirdly, they may increase stress and lower the threshold for aggression, thereby triggering bullying. A further cause for concern is the fact that over time bullying may be built into organisational routines, in the sense that both the victim and the perpetrator perceive themselves as victims of the system. This is when we are justified in talking about organisational bullying [55] or systemic/structural abuse [52].

\section{Conclusions}

This study showed a positive correlation between a high degree of organisational politics and bullying. Thus, bullying particularly seems to flourish in hectic and competitive environments, where employees are willing to sabotage the work performance of colleagues and to expel unwanted colleagues and subordinates in order to improve their own position. However, it is worth noting that this study did 
not aim to establish causality between variables. The possible underlying causal mechanisms between a variety of factors, as well as the strength of the links between the variables will be further analysed in the ongoing research project, in order to be able to more clearly establish the dynamics of organisational politics and bullying.

However, since bullying has been shown to be costly for organisations and society as a whole [2-3], the finding that organisational politics and bullying are associated has important implications for managers and decision-makers. The fact that in some cases bullying can be at least partly explained as a deliberate competitive strategy in organisations characterised by increased pressures for efficiency and increased internal competition must also be taken into consideration when deciding on appropriate prevention and intervention measures. In brief, the managerial implications are that managers need to ensure that the reward system does not even indirectly encourage bullying and sabotage, and to ensure that the perpetrators perceive the costs of bullying as higher than are the likely benefits.

\section{Acknowledgements}

The author wishes to thank The Finnish Association of Graduates in Economics and Business Administration (SEFE) for their generous assistance in the datacollection process. Thanks are also due to Professors Jeff Hearn and Anne Kovalainen and to the Guest Editors of this issue and organisers of the Bullying Symposium at the SCOS-Conference 2002, Dr Michael Sheehan and Duncan Lewis, for their constructive comments.

\section{References}

1 Einarsen, S. \& Gemzøe Mikkelsen, E. (2002, in press) 'Individual effects of exposure to bullying at work' in Einarsen, S., Hoel, H., Zapf, D. \& Cooper, C. 
Bullying and Emotional Abuse in the Workplace: International Perspectives in Research and Practice, London: Taylor \& Francis.

2 Leymann, H. (1992) Vuxenmobbning på svenska arbetsplatser. En rikstäckande undersökning med 2.428 intervjuer. [Adult bullying at Swedish workplaces: a nation-wide study based on 2,428 interviews], Stockholm: Arbetarskyddsstyrelsen.

3 Rayner, C. (2000) 'Building a business case for tackling bullying in the workplace: beyond a basic cost-benefit approach', in Sheehan, M., Ramsay, S. \& Patrick, J (Eds.) Transcending Boundaries: Integrating People, Processes and Systems. Proceedings of the 2000 Conference, Brisbane, Queensland, Australia. Brisbane: Griffith University, pp. 26-31.

4 Coyne, I., Seigne, S. \& Randall, P. (2000) 'Predicting workplace victim status from personality', European Journal of Work and Organizational Psychology, Vol. 9, No. 3, pp. 335-349.

5 Einarsen, S., Raknes, B.I. \& Matthiesen, S.B. (1994) 'Bullying and harassment at work and their relationships to work environment quality: an exploratory study’, European Work and Organizational Psychologist, Vol. 4, No. 4, pp. 381-401.

6 Einarsen, S. (1999) 'The nature and causes of bullying at work', International Journal of Manpower, Vol. 20, No. 1-2, pp. 16-27.

7 Neuman, J.H. \& Baron, R.A. (1998) 'Workplace violence and workplace aggression: evidence concerning specific forms, potential causes, and preferred targets', Journal of Management, Vol. 24, No. 3, pp. 391-419.

8 Vartia, M. (1996) 'The sources of bullying - psychological work environment and organizational climate', European Journal of Work and Organizational Psychology, Vol. 5, No. 2, pp. 203-214.

9 Zapf, D., Knorz, C. \& Kulla, M. (1996) 'On the relationship between mobbing factors, and job content, social work environment, and health outcomes', 
European Journal of Work and Organizational Psychology, Vol. 5, No. 2, pp. 215-237.

10 Zapf, D. (1999) 'Organisational, work group related and personal causes of mobbing/bullying at work', International Journal of Manpower, Vol. 20, No. 1-2, pp. 70-85.

11 Adams, A. (1992) Bullying at Work: How to Confront and Overcome It. London: Virago Press.

12 Field, T. (1996) Bully in Sight: How to Predict, Resist, Challenge and Combat Workplace Bullies, London: Success Unlimited.

13 Randall, P. (1997) Adult Bullying: Perpetrators and Victims, London: Routledge.

14 Aquino, K., Grover, S., Bradfield, M. \& Allen, D. (1999) 'The effects of negative affectivity, hierarchical status, and self-determination on workplace victimization', Academy of Management Journal, Vol. 42, No. 3, pp. 260-272.

15 Leymann, H. (1996) 'The content and development of mobbing at work', European Journal of Work and Organizational Psychology, Vol. 5, No. 2, pp. 165-184.

16 Einarsen, S. \& Skogstad, A. (1996) 'Bullying at work: epidemiological findings in public and private organizations', European Journal of Work and Organizational Psychology, Vol. 5, No 2, pp. 185-201.

17 Thylefors, I. (1987) Syndabockar - om utstötning och mobbning i arbetslivet. [Scapegoats - about exclusion and bullying in work life], Natur och Kultur. Stockholm.

18 Hoel, H. \& Cooper, C.L. (2000) Destructive Conflict and Bullying at Work, Manchester School of Management, University of Manchester Institute of Science and Technology. 
19 Appelberg, K., Romanov, K., Honkasalo, M. \& Koskenvuo, M. (1991) 'Interpersonal conflicts at work and psychosocial characteristics of employees’, Social Science Medicine, Vol. 32, pp. 1051-1056.

20 UNISON (1997) UNISON Members' Experience of Bullying at Work. London: UNISON.

21 Robinson, S.L. \& O'Leary-Kelly, A.M. (1998) 'Monkey see, monkey do: the influence of work groups on the antisocial behavior of employees', Academy of Management Journal, Vol. 41, No. 6, pp. 658-672.

22 McCarthy, P. (1996) 'When the mask slips: inappropriate coercion in organisations undergoing restructuring', in McCarthy, P., Sheehan, M. \& Wilkie, D. (Eds): Bullying: From Backyard to Boardroom. Alexandria: Millennium Books.

23 Sheehan, M. (1996) 'Case studies in organisational restructuring', in McCarthy, P.; Sheehan, M. \& Wilkie, D. (Eds): Bullying: From Backyard to Boardroom, Alexandria: Millennium Books.

24 Baron, R.A. \& Neuman, J.H. (1996) 'Workplace violence and workplace aggression: evidence on their relative frequency and potential causes', Aggressive Behavior, Vol. 22, pp. 161-173.

25 Neuberger, O. (1999) Mobbing: Übel Mitspielen in Organisationen, $3^{\text {rd }}$ revised edition, München: Rainer Hampp Verlag.

26 Niedl, K. (1995): 'Wem nützt Mobbing? Psychoterror am Arbeitsplatz and die Personalwirtschaft von Unternehmen', in Leymann, H. (Ed.) Der neue Mobbing-Bericht: Erfahrungen and Initiativen, Auswege und Hilfsangebote, Reinbek bei Hamburg: Rowohlt Taschenbuch Verlag GmbH.

27 Zapf, D. \& Warth, K. (1997) 'Mobbing: Subtile Kriegsführung am Arbeitsplatz', Psychologie Heute, August, pp. 20-25; 28-29.

28 Leymann, H. (1995) Der neue Mobbing-Bericht: Erfahrungen and Initiativen, Auswege und Hilfsangebote, Reinbek bei Hamburg: Rowohlt Taschenbuch Verlag GmbH. 
29 Kräkel, M. (1997) 'Rent-seeking in Organisationen - eine ökonomische Analyse sozial schädlichen Verhaltens', Schmalenbachs Zeitschrift für Betriebswirtschaftliche Forschung, Vol. 49, No. 6, pp. 535-555.

30 O'Moore, M. (2000) Summary Report on the National Survey on Workplace Bullying in Ireland. The Anti-Bullying Research Centre, Trinity College, Dublin.

31 Klein, S. (1996) 'A longitudinal study of the impact of work pressures on group cohesive behaviors', International Journal of Management, Vol. 13, No. 1, pp. 68-75.

32 Labour Research (1994) Unions take on workplace bullies, August, pp. 15-16, cited in Lee, D. (2000) 'An analysis of workplace bullying in the UK', Personnel Review, Vol. 29, No. 5, pp. 593-612.

33 Allen, R.W., Madison, D.L., Porter, L.W., Renwick, P.A. \& Mayes, B.T. (1979) 'Organizational politics: tactics and characteristics of its actors', California Management Review, Vol. 22, No. 1, pp. 77-83.

34 Kacmar, M.L. \& Ferris, G.R. (1993) 'Politics at work: sharpening the focus of political behavior in organizations’, Business Horizons, Vol. 36, No. 4, pp. 7074.

35 Kacmar, M.L. \& Ferris, G.R. (1991) 'Perceptions of organizational politics scale (POPS): development and construct validation', Educational \& Psychological Measurement, Vol. 51, No. 1, pp. 193-205.

36 Nye, L.G. \& Witt, L.A. (1993) 'Dimensionality and construct validity of the perceptions of politics scales (POPS)', Education and Psychological Measurement, Vol. 53, No. 3, pp. 821-829.

37 Reichel, A. \& Neuman, Y. (1993) 'Work stress, job burnout, and work outcomes in a turbulent environment. The case of Israeli Executives', International Studies of Management \& Organisation, Vol. 23, No. 3, pp. 7596. 
38 Einarsen, S. (1996) Bullying and Harassment at Work: Epidemiological and Psychosocial Aspects, Doctoral dissertation, Bergen: University of Bergen.

39 Salin, D. (2001) 'Prevalence and forms of bullying among business professionals: a comparison of two different strategies for measuring bullying', European Journal of Work and Organizational Psychology, Vol. 10, No. 4, pp. 425-441.

40 Einarsen, S. \& Raknes, B. (1997) 'Harassment in the workplace and the victimization of men', Violence and Victims, Vol, 12, No. 3, pp. 247-263.

41 Leymann, H (1989) Presentation av LIPT-formuläret: konstruktion, validering, utfall. [Leymann Inventory of Psychological Terrorization: Development, Validation and Results], Stockholm: Violen.

42 All translations of the written stories were made by the present author

43 Gandz, J. \& Murray, V. (1980) 'The experience of workplace politics', Academy of Management Journal, Vol. 23, No. 2, pp. 237-251.

44 DiTomaso, N. (1989) 'Sexuality in the workplace: discrimination and harassment', in Hearn, J., Sheppard, D., Tancred-Sheriff, P. \& Burrell, G. (Eds.) The Sexuality of Organization, London: Sage Publications.

45 Mintzberg, H. (1985) 'The organization as political arena', Journal of Management Studies, Vol. 22, No. 2, p.133-154.

46 Fandt, P.M. \& Ferris, G.R. (1990) 'The management of information and impressions: when employees behave opportunistically', Organizational Behavior and Human Decision Processes, Vol. 43, No. 1, pp. 140-158.

47 Ferris, G., Frink, D., Galang, M., Zhou, J., Kacmar, M. \& Howard, L. (1996) 'Perceptions of organizational politics: prediction, stress-related implications, and outcomes', Human Relation, Vol. 49, No. 2, pp. 233-266.

48 Valle, M \& Perrewe, P. (2000) 'Do politics perceptions relate to political behaviors? Tests of an implicit assumption and expanded model', Human Relations, Vol. 53, No. 3, pp. 359-386. 
49 Kivimäki, M., Elovainio, M. \& Vahtera, J. (2000) 'Workplace bullying and sickness absence in hospital staff', Occupational and Environmental Medicine, Vol. 57, pp. 656-660.

50 Salin, D. (1999) Explaining Workplace Bullying: A Review of Enabling, Motivating, and Triggering Factors in the Work Environment, Working paper no 406, Helsinki: Swedish School of Economics and Business Administration.

51 Björkqvist, K., Österman, K. \& Lagerspetz, K. (1994) 'Sex differences in covert aggression among adults', Aggressive Behaviour, Vol. 20, No. 1, pp. 27-33.

52 Wright, L. \& Smye, M. (1997) Corporate Abuse: How 'Lean and Mean' Robs People and Profit, New York: Simon and Schuster.

53 Lee, D. (2000) 'An analysis of workplace bullying in the UK', Personnel Review, Vol. 29, No. 5, pp. 593-612.

54 NASUWT (1996) No place to hide: confronting workplace bullies, Birmingham: NASUWT, cited in Lee, D. (2000) 'An analysis of workplace bullying in the UK', Personnel Review, Vol. 29, No. 5, pp. 593-612.

55 Liefooghe, A.P.D. \& Mackenzie Davey, K. (2001) 'Accounts of workplace bullying: the role of the organization', European Journal of Work and Organizational Psychology, Vol. 10, No. 4, pp. 375-392. 


\section{Appendix A}

One group always gets their way

Influential group no one crosses

Policy changes help only a few

Some build up themselves by tearing others down

Favouritism not merit gets people ahead

Don't speak up for fear of retaliation

Promotions go to top performers (Reverse coded)

Rewards come to hard workers (Reverse coded)

Encouraged to speak out (Reverse coded)

Safer to agree with management than to say what you think is right

Pay/promotion based solely on merit (Reverse coded)

Pay/promotion decision consistent with policies (Reverse coded)

Appendix A - Items included in the Perceptions of Organizational Politics Scale, developed by Kacmar and Ferris [34], with the slight modifications suggested by Nye and Witt [36] (1993). 
Figure 1 - Spearman correlation coefficients between bullying, organisational politics, internal competition and work overload $(362<\mathbf{n}<367)$

\begin{tabular}{|l|cccc|}
\hline & 1. Bullying & $\begin{array}{c}\text { 2. Organisational } \\
\text { politics }\end{array}$ & $\begin{array}{c}\text { 3. Internal } \\
\text { competition }\end{array}$ & $\begin{array}{c}\text { 4. Work } \\
\text { overload }\end{array}$ \\
\hline 1. Bullying & 1.000 & - & - & - \\
2. Org. politics & $.300^{* *}$ & 1.000 & - & - \\
3. Int. competition & $.105^{*}$ & $.377^{* *}$ & 1.000 & - \\
4. Work overload & $.088^{*}$ & $.221^{* *}$ & $.199 * *$ & 1.000 \\
\hline
\end{tabular}

** Correlation is significant at the 0.01 level (2-tailed).

* Correlation is significant at the 0.05 level (2-tailed).

Figure 2 - The correlation between bullying, internal competition and stress when controlling for organisational politics $(n=349)$

\begin{tabular}{|l|lll|}
\hline & Bullying & $\begin{array}{l}\text { Internal } \\
\text { competition }\end{array}$ & Work overload \\
\hline Bullying & 1.000 & - & - \\
$\begin{array}{l}\text { Internal } \\
\text { competition }\end{array}$ & $\begin{array}{l}-0.101 \\
(\mathrm{p}=0.058)\end{array}$ & 1.000 & - \\
Work overload & $\begin{array}{l}0.0203 \\
(\mathrm{p}=0.704)\end{array}$ & $\begin{array}{l}0.1423 \\
(\mathrm{p}=0.008)\end{array}$ & 1.000 \\
\hline
\end{tabular}

